\title{
Retraction Note to: Urban air pollution diffusion status and sports training physical fitness measurement based on the Internet of things system
}

\section{Guiling Chang ${ }^{1}$}

Published online: 3 November 2021

c) Saudi Society for Geosciences 2021

Retraction Note to: Arabian Journal of Geosciences (2021) 14: 1555

https://doi.org/10.1007/s12517-021-07947-x

The Editor-in-Chief and the Publisher have retracted this article because the content of this article is nonsensical. The peer review process was not carried out in accordance with the Publisher's peer review policy. The author has not responded to correspondence regarding this retraction.

Publisher's note Springer Nature remains neutral with regard to jurisdictional claims in published maps and institutional affiliations.

The original article can be found online at https://doi.org/10.1007/ s12517-021-07947-x.

Guiling Chang

changguilingxa@126.com

1 Xi' an University of Finance and Economics, Xi' an 710100,

Shaanxi, China 